DOI: https://doi.org/10.24127/ajpm.v8i1.1957

\title{
PENGEMBANGAN BAHAN AJAR MATEMATIKA BERBASIS KOMPUTER MENGGUNAKAN FLIPBOOK MAKER DISERTAI NILAI ISLAM PADA MATERI PELUANG
}

\author{
Aris Munandar ${ }^{1}$, Swaditya Rizki ${ }^{*}$ \\ ${ }^{1,2}$ Pendidikan Matematika, Universitas Muhammadiyah Metro \\ *Corresponding author. Address: Department of Mathematics Education, Muhammadiyah University of Metro, \\ 34111, Lampung, Indonesia \\ E-mail: $\quad$ arismm96@yahoo.com ${ }^{1)}$ \\ swadityarizki@ummetro.ac.id ${ }^{2 *}$
}

Received 26 March 2019; Received in revised form 8 May 2019; Accepted 14 May 2019

\begin{abstract}
The objective of the research was to produce computer-based learning materials of probability using flipbook maker accompanied by Islamic value. The type of this research was development refers to the development model in Sugiyono's opinion through 7 stages, potential and problems, data collection, product design, design validation, design revision, product trial, and product revision. The research instruments were questionnaire of validation expert of material and design, and the student response questionnaire. The result of material expert validation was obtained a percentage of $84 \%$ so that it was declared very feasible, the design expert validation was obtained from $78 \%$ so that it was declared feasible, and then the validation of Islamic values experts was obtained a percentage of 92\%, so it was declared very feasible. From the student response was obtained the percentage of $89 \%$, so that the learning material could be declared very practical. Based on the results of the study, it can be concluded that the learning media produced is very feasible, while the response of students to learning media is very practical. Mathematics teaching materials using flipbook makers are available to teach independent teaching materials and shape good characters and morals with the Islamic values as learning.
\end{abstract}

Keywords: flipbook maker;ICT; Islamic values; $R \& D$

\section{PENDAHULUAN}

Dalam era revolusi industri 4.0, teknologi memiliki peranan yang sangat penting untuk meningkatkan kualitas proses pembelajaran. Salah satu langkah strategisnya yaitu mengembangan bahan ajar berbasis teknologi dan informasi, sehingga dapat meningkatkan minat peserta didik dalam proses pembelajaran.

Beberapa penelitian dan pengembangan yang memanfaatkan teknologi dan informasi telah banyak dikembangkan oleh peneliti-peneliti di seluruh dunia seperti yang dilakukan oleh Korucu dan Gunduz (2011); Aqda, Hamidi, dan Rahimi (2011); Dost and Saglam (2012); Istiqlal dan Wutsqa (2013); Novaliendry (2013); Riyadi dan
Pardjono (2014); Fahmi dan Marsigit (2014); Nugraha dan Muhtadi (2015); Bardi dan Jailani (2015); Khuzaini dan Santosa (2016); Mardiana dan Qohar (2017); Yusri dan Husaini (2017). Penelitian-penelitian tersebut terkait dengan pemanfaatan teknologi komputer dalam proses pembelajaran. Semua penelitian tersebut menyimpulkan bahwa ada manfaat yang positif dalam proses pembelajaran.

Kebaruan penelitian ini dengan penelitian sebelumnya yaitu bahan ajar ini memanfaatkan teknologi komputer menggunakan flipbook maker disertai nilai Islam. Sedangkan pada penelitian sebelumnya hanya memanfaatkan komputer saja. Namun, pendidik sebagai pendidik profesional belum 
memiliki bahan ajar yang inovatif, tidak hanya itu namun bahan ajar juga yang sesuai dengan kebutuhan peserta didik dengan memperhatikan karakteristik, lingkungan sosial peserta didik. Pendidikan juga mampu mengembangkan bahan ajar mengikuti teknologi informasi dan komunikasi. Proses pengembangan suatu bahan ajar harus memperhatikan karakteristik peserta didik khususnya Sekolah Menengah Kejuruan. Menurut Mulyadi (2016) menyatakan bahwa Kvisoft Flipbook Maker yang merupakan perangkat lunak yang digunakan untuk membuat tampilan buku atau bahan ajar lainnya menjadi sebuah buku elektronik digital berbentuk Flipbook maker. Oleh karena itu bahan ajar ini sangat mudah dan praktis untuk dipelajari.

Bahan ajar juga belum memanfaatkan komputer sebagai media yang sudah tersedia di SMK Muhammadiyah 2 Metro sekolah juga sudah menyediakan komputer. Proses pembelajaran dengan memperhatikan kebutuhan dan potensi yang sudah ada di SMK Muhammadiyah 2 Metro diperlukan sebuah solusi. Pengembangan bahan ajar pada materi peluang dengan menyajikan contohcontoh dalam bahan ajar yang menggunakan flipbook maker yang lebih mudah dengan menambahkan nilai-nilai islam yang diambil dari ayatayat Al- Quran, As-Sunnah dan AsShohih yang sudah ditafsirkan merupakan salah satu solusi untuk mengatasi permasalahan tersebut. Nilainilai Islam adalah sifat-sifat atau dasar keimanan, kepribadian, serta budi pekerti yang baik yang dibingkai dalam aturan islam untuk memperbaiki akhlak dan perilaku manusia (Rahmawati dan Rizki, 2017). Peserta didik diharapkan selain paham dengan isi materi yang disampaikan dapat berimbas pada terbentuknya akhlak dan karakter yang baik. Setelah itu pengembangan bahan ajar menggunakan flipbook maker dikemas secara digital, bisa dibuka layaknya kertas dan lembaran-lembaran kertas dilayar monitor yang diakses dengan komputer.

Solusi untuk menyelesaikan masalah tersebut yaitu diperlukan inovasi bahan ajar berbasis komputer dan nilai Islam. Oleh karena itu, tujuan penelitian ini yaitu untuk menghasilkan bahan ajar berbasis komputer menggunakan flipbook maker disertai nilai Islam pada materi peluang yang valid dan praktis.

\section{METODE PENELITIAN}

Model pengembangan yang diambil yaitu model pengembangan yang dilakukan oleh Sugiyono (2016) yaitu potensi dan masalah, proses dimana mengetahui kondisi dilapangan dan memecahkan masalah berkaitan proses belajar mengajar matematika di SMK Muhammadiyah 2 Metro. Sehingga didapat masalah yang ada dengan solusi mengembangkan bahan ajar matematika berupa buku elektronik berbasis islam untuk mengatasi kebutuhan peserta didik memiliki bahan ajar mandiri dan mengembangkan potensi yang ada di SMK Muhammadiyah 2 Metro.

Pengumpulan data, perencanaan produk tertentu yang diharapkan dapat mengatasi masalah tersebut. Pada tahap ini pengumpulan informasi dilakukan dengan dilakukan observasi dan wawancara dengan pendidik dan peserta didik di SMK Muhammadiyah 2 Metro.

Desain produk berupa desain produk bahan ajar berbasis komputer menggunakan flipbook maker disertai nilai Islam. Validasi desain dilakukan untuk menilai produk yang divalidasi ahli materi, ahli nilai islam dan ahli media guna melihat kelayakan pada 
produk. Revisi desain dilakukan untuk mengetahui kekurangan pada produk flipbook maker berbasis nilai islam, setelah dilakukan revisi kekurangan produk melalui tahap validasi oleh para ahli dan sudah dinyatakan layak dapat langsung diujicobakan.

Uji coba produk, produk diujicobakan di SMK Muhammadiyah 2 Metro. Sampel yang digunakan adalah kelas XI kelompok kecil terdiri dari 10 orang peserta didik. Peserta didik diberikan bahan ajar dan diminta untuk memberikan respon tentang bahan ajar yang menggunakan flipbook maker berbasis nilai islam materi Peluang.

Setelah uji coba produk dilakukan maka dilakukan revisi produk kembali untuk memperbaiki kelemahankelamahan dan kesalahan yang masih ada guna menyempurnakan produk bahan ajar yang dikembangkan.

Teknik analisis data pengembangan ini adalah analisis validasi pakar dan analisis kepraktisan produk. Apabila hasil yang diperoleh sudah mencapai kriteria minimal 60\% maka produk bahan ajar sudah layak untuk digunakan dalam proses belajar. Kepraktisan bahan ajar ini mempunyai batas minimal yaitu harus mendapatkan persentase lebih dari $60 \%$ atau setuju. Setelah menganalisis persentase kepraktisan dari respon siswa, juga dilakukan analisis saran dan komentar bahan ajar dari siswa untuk memperbaiki bahan ajar menjadi bahan ajar yang lebih baik.

\section{HASIL PENELITIAN DAN PEMBAHASAN}

Bahan ajar matematika berbasis komputer menggunakan materi peluang disertai Nilai Islam Kelas XI SMK dikembangkan berupa buku elektronik menggunakan Flipbook Maker. Produk bahan ajar tersebut disajikan pada Gambar 1-2.

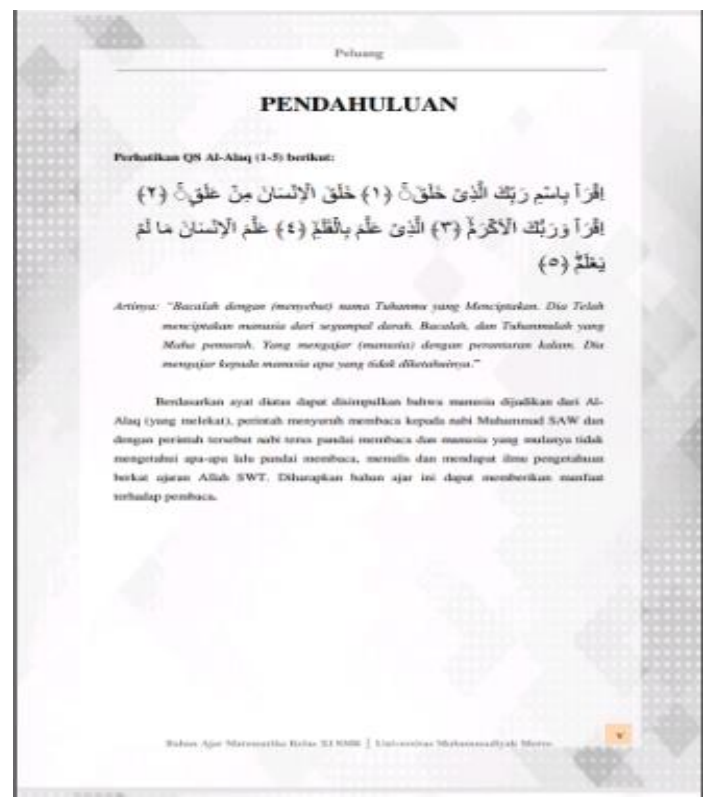

Gambar 1. Tampilan pendahuluan bahan ajar. 
DOI: https://doi.org/10.24127/ajpm.v8i1.1957

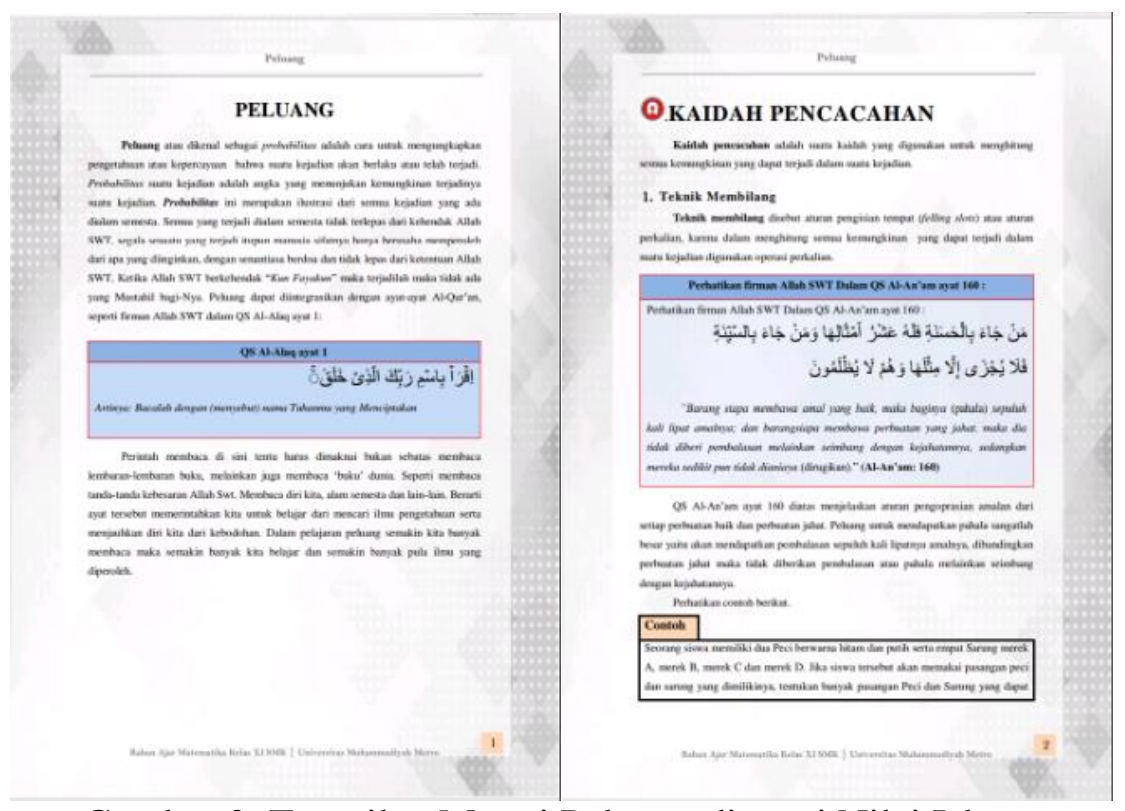

Gambar 2. Tampilan Materi Peluang disertai Nilai Islam.

Data diperoleh dari hasil validasi yang dilakukan oleh 5 validator yaitu 2 ahli materi yang terdiri dari 1 dosen Pendidikan MatematikaUniversitas Muhammadiyah Metro dan 1 guru SMK Muhammadiyah 2 Metro, 2 ahli desain yang terdiri dari 2 dosen Pendidikan
Matematika Universitas Muhammadiyah Metro, dan 1 ahli nilai Islam (Tafsir) yang terdiri dari 1 dosen Fakultas Agama Islam Universitas Muhammadiyah Metro. Rata-rata persentase hasil dari validasi terhadap para ahli disajikan pada Tabel 1.

Tabel 1. Rata-Rata Persentase Tingkat Kelayakan Bahan Ajar.

\begin{tabular}{ccc}
\hline Validator & Rata-rata Persentase & Kategori \\
\hline Ahli Materi & $84,57 \%$ & Sangat Layak \\
Ahli Desain & $78,34 \%$ & Layak \\
Ahli Nilai Islam & $92 \%$ & Sangat Layak \\
\hline Rata-rata & $89,33 \%$ & Sangat Layak \\
\hline
\end{tabular}

Berdasarkan Tabel 1, data hasil perhitungan sehingga diperoleh persentase masing-masing aspek yaitu ahli materi 84,57\%, aspek desain
$78,34 \%$, aspek nilai islam $92 \%$ dan diperoleh rata-rata yang diberikan oleh validator adalah $89,33 \%$ termasuk kedalam kategori sangat layak.

Tabel 2. Data Analisis Respon Peserta Didik

\begin{tabular}{lccc}
\hline \multicolumn{1}{c}{ Peserta Didik } & Skor & $\begin{array}{c}\text { Rata-rata } \\
\text { Persentase }\end{array}$ & Kategori \\
\hline Arif Setiawan & 67 & $89,33 \%$ & Sangat Praktis \\
Dicki Andeska & 60 & $80,00 \%$ & Praktis \\
Dion Priaji & 70 & $93,33 \%$ & Sangat Praktis \\
Edi Kiswanto & 70 & $93,33 \%$ & Sangat Praktis \\
\hline
\end{tabular}


DOI: https://doi.org/10.24127/ajpm.v8i1.1957

\begin{tabular}{lccc}
\hline Fachrul Febriansyach & 69 & $92,00 \%$ & Sangat Praktis \\
Faradila Sandi & 68 & $90,67 \%$ & Sangat Praktis \\
Hesti Adila & 66 & $88,00 \%$ & Sangat Praktis \\
Imam Afriandi & 71 & $94,67 \%$ & Sangat Praktis \\
Muhammad Rizky Hakiki & 67 & $89,33 \%$ & Sangat Praktis \\
Tri Susanto & 62 & $82,67 \%$ & Sangat Praktis \\
\hline \multicolumn{1}{c}{ Jumlah } & $\mathbf{6 7 0}$ & $\mathbf{8 9 , 3 3 \%}$ & Sangat Praktis \\
\hline
\end{tabular}

Tabel 3. Data Penilaian Indikator Angket Respon Peserta Didik

\begin{tabular}{|c|c|c|c|c|}
\hline $\begin{array}{l}\text { No. } \\
\text { Item }\end{array}$ & Indikator & $\begin{array}{l}\text { Jumlah } \\
\text { Skor }\end{array}$ & $\begin{array}{l}\text { Rata-rata } \\
\text { Persentase }\end{array}$ & Kategori \\
\hline 1 & $\begin{array}{l}\text { Petunjuk penggunaan sudah } \\
\text { jelas. }\end{array}$ & 45 & $90 \%$ & Sangat Praktis \\
\hline 2 & $\begin{array}{l}\text { Materi yang disampaikan } \\
\text { sudah jelas dan menarik. }\end{array}$ & 45 & $90 \%$ & Sangat Praktis \\
\hline 3 & $\begin{array}{l}\text { Materi ditampilkan secar } \\
\text { runtun (teratur). }\end{array}$ & 47 & $94 \%$ & Sangat Praktis \\
\hline 4 & $\begin{array}{l}\text { Materi yang disajikan mudah } \\
\text { dipahami }\end{array}$ & 47 & $94 \%$ & Sangat Praktis \\
\hline 5 & $\begin{array}{l}\text { Kualitas gambar yang } \\
\text { dutampilkan sesuai. }\end{array}$ & 45 & $90 \%$ & Sangat Praktis \\
\hline 6 & $\begin{array}{l}\text { Kombinasi warna yang } \\
\text { digunakan sesuai. }\end{array}$ & 38 & $76 \%$ & Praktis \\
\hline 7 & $\begin{array}{l}\text { Gambar dalam bahan ajar } \\
\text { menarik. }\end{array}$ & 41 & $82 \%$ & Sangat Praktis \\
\hline 8 & $\begin{array}{l}\text { Tombol navigasi mudah } \\
\text { dipahami. }\end{array}$ & 48 & $96 \%$ & Sangat Praktis \\
\hline 9 & $\begin{array}{l}\text { Teks dapat dibaca dengan } \\
\text { jelas. }\end{array}$ & 43 & $86 \%$ & Sangat Praktis \\
\hline 10 & $\begin{array}{l}\text { Soal yang ditampilkan sudah } \\
\text { baik. }\end{array}$ & 44 & $88 \%$ & Sangat Praktis \\
\hline 11 & $\begin{array}{lll}\text { Media mudah } & \text { untuk } \\
\text { digunakan. } & \end{array}$ & 46 & $92 \%$ & Sangat Praktis \\
\hline 12 & $\begin{array}{l}\text { Dapat memudahkan dalam } \\
\text { belajar. }\end{array}$ & 49 & $98 \%$ & Sangat Praktis \\
\hline 13 & $\begin{array}{l}\text { Dapat memberikan bantuan } \\
\text { dalam belajar. }\end{array}$ & 45 & $90 \%$ & Sangat Praktis \\
\hline 14 & $\begin{array}{l}\text { Dapat dijadikan media belajar } \\
\text { secara mandiri. }\end{array}$ & 48 & $96 \%$ & Sangat Praktis \\
\hline 15 & $\begin{array}{l}\text { Keinginan untuk mempelajari } \\
\text { materi dengan media sejenis. }\end{array}$ & 45 & $90 \%$ & Sangat Praktis \\
\hline
\end{tabular}

Berdasarkan analisis data Tabel 2, masing-masing angket respon peserta didik di atas, selanjutnya dilakukan peritungan rata-rata persentase untuk melihat tingkat kepraktisan bahan ajar matematika, diperoleh sebesar 89,33\% dan dengan hasil tersebut maka peserta didik sangat setuju dengan bahan ajar 
DOI: https://doi.org/10.24127/ajpm.v8i1.1957

yang dikembangkan serta masuk dalam kategori sangat praktis.

Berdasarkan Tabel 3, penilaian peserta didik tentang indikator angket respon peserta didik diperoleh data yaitu satu indikator menunjukan angka $76 \%$ tentang kombinasi gambar bahan ajar digunakan. Sedangkan 14 indikator lainya menunjukan angka rata lebih dari $80 \%$ dan termasuk dalam kategori sangat praktis.

Produk yang dikembangkan bahan ajar menggunakan flipbook maker materi peluang yang berbasis nilai islam. Tampilan bahan ajar yang dikembangkan yaitu halaman depan (cover) berisikan judul, logo dan instansi Universitas Muhammadiyah Metro. Pendahuluan berisikan QS AlAlaq (1-5) sebagai pengantar bahan peluang. Halaman Peluang matematika dengan kaitan nilai-nilai islam ketika Allah berkehendak maka "kun fayakun" maka terjadilah dan tidak ada yang mustahil bagi-Nya. Bagian isi bahan ajar mencakup materi yang dengan nilai islam, contoh soal dan soal uji kopetensi yang dikaitkan dengan nilai islam. Bagian Akhir bahan ajar rangkuman dari semua subbab materi dan soal evaluasi ahir berupa pilihan ganda dan soal essay.

Bahan ajar matematika menggunakan flipbook maker mampu mengatasi kebutuhan peserta didik dan mengembangkan potensi yang ada di SMK Muhammadiyah 2 Metro. Seperti peserta didik dapat memiliki bahan ajar mandiri, selain itu juga untuk membentuk karakter dan akhlak yang baik bahan ajar ini pula memberikan wawasan baru mengenai materi peluang yang berbasis nilai islam dengan menggunakan fasilitas yang sudah ada dan dapat digunakan dengan mudah berbentuk buku elektronik menggunakan flipbook maker.
Berdasarkan hasil dari dua tahap yang telah dilakukan, diperoleh persentase sebagai berikut: 1) ahli materi dengan rata persentase $84,57 \%$ berkriteria "sangat layak", 2) ahli desain dengan rata-rata persentase $78,34 \%$ berkriteria "layak", 3) ahli nilai islam (tafsir) dengan rata-rata persentase 92\% berkriteria "sangat layak". tahap kedua yaitu uji coba produk yang diambil dari angket respon peserta didik didapatkan rata-rata persentase $89,33 \%$ dengan kriteria "sangat praktis".

Pengembangan bahan ajar menggunakan flipbook maker materi peluang berbasis nilai islam ini memiliki beberapa kelebihan untuk digunakan dalam proses pembelajaran, bahan ajar ini bisa dimiliki dan diakses secara mandiri oleh peserta didik, memberikan wawasan baru mengenai materi peluang yang berbasis nilai-nilai Islam, bahan ajar ini tidak perlu dicetak dan dapat meminimkan biaya. Kelebihan lain dari bahan ajar ini yaitu mengintegrasikan teknologi kedalam proses pembelajaran. Di samping itu, bahan ajar ini memuat nilai-nilai Islam sehingga dapat menambah pengetahuan akademik dan agama secara bersamaan.

Dari hasil penelitian ini, implikasi yang didapatkan yaitu mahasiswa menjadi tertarik dan mudah untuk mempelajari matematika khususnya pada materi peluang. Pemanfaatan teknologi dan juga pengintegrasian nilai Islam dalam bahan ajar dapat meningkatkan minat peserta didik dalam mempelajari materi peluang. Hal ini sejalan dengan penelitian yang dilakukan oleh Korucu dan Gunduz (2011); Aqda, Hamidi, dan Rahimi (2011); Dost and Saglam (2012); Istiqlal dan Wutsqa (2013); Novaliendry (2013); Riyadi dan Pardjono (2014); Fahmi dan Marsigit (2014); Nugraha dan Muhtadi (2015); Bardi dan Jailani (2015); Khuzaini dan 
Santosa (2016); Mardiana dan Qohar (2017); Yusri dan Husaini (2017) yang menyatakan bahwa pemanfaatan teknologi komputer memiliki dampak positif dalam proses pembelajaran. Sedangkan untuk nilai-nilai Islam, penelitian ini sejalan dengan penelitian yang dilakukan oleh Rahmawati dan Rizki (2017); Khoiriyah dan Rizki (2017) yang menyatakan bahwa nilainilai Islam dapat meningkatan pengetahuan tentang matematika dan agama Islam.

\section{KESIMPULAN DAN SARAN}

Dari hasil penelitian dan pengembangan dapat disimpulkan bahwa bahan ajar berbasis komputer menggunakan flipbook maker disertai nilai Islam pada materi peluang dinyatakan "sangat layak" dan "sangat praktis" sehingga bahan ajar tersebut dapat memenuhi kebutuhan peserta didik. Penggunaan teknologi seperti komputer dapat menarik minat belajar matematika peserta didik karena proses pembelajarannya dianggap menarik. Bahan ajar ini juga dapat dimanfaatkan oleh peserta didik dengan mudah.

Berdasarkan penelitian dan pengembangan yang telah dilakukan maka terdapat saran untuk penelitian selanjutnya yaitu penelitian ini perlu dilakukan ujicoba efektifitas pada kelompok yang lebih besar sehingga bahan ajar ini bisa dimanfaatkan dalam skala yang lebih luas lagi.

\section{DAFTAR PUSTAKA}

Aqda, M. F., Hamidi, F., \& Rahimi, M. (2011). The comparative effect of computer-aided instruction and traditional teaching on student's creativity in math classes. The Journal of
Procedia Computer Science 3:Elsevier, p.266-270.

Dost, S. \& Saglam, Y. (2012). Effect of preservice teachers' learning styles and field of study on computer-assisted instruction. The Journal of Procedia Social and Behavioral Sciences 46: Elsevier, p.3812-3816

Khoiriyah, U. \& Rizki, S. (2017). Pengembangan Bahan Ajar Himpunan Matematika Dikaitkan Dengan Nilai-Nilai Islam. AKSIOMA Jurnal Pendidikan Matematika. Vol.6. No.3. Hal 315-322. Universitas Muhammadiyah Metro.

Korucu, A.T. \& Gunduz, S. (2011). The effects of computer assisted instruction practices in computer office program course on academic achievements and attitudes toward computer. The Journal of Procedia Social and Behavioral Sciences 15: Elsevier, p.1931-1935.

Mulyadi, dkk. (2016). Pengembangan Media Flash Flipbook Untuk Meningkatkan Keterampilan Berfikir Kreatif Siswa Dalam Pembelajaran IPA di SMP. Jurnal Pendidikan Fisika. Vol.4. No.4. Hal. 298.

Rahmawati, A. \& Rizki, S. (2017). Pengembangan Bahan Ajar Matematika Berbasis Nilai-Nilai Islam Pada Materi Aritmatika Sosial. AKSIOMA Jurnal Pendidikan Matematika. Vol.6. No.1. Hal 81-88. Universitas Muhammadiyah Metro. 
DOI: https://doi.org/10.24127/ajpm.v8i1.1957

Sugiyono. (2016). Metode Penelitian Kuantitatif, Kualitatif, dan $R \& D$. Alfabeta. Bandung.

Bardi \& Jailani. (2015). Pengembangan Multimedia Berbasis Komputer Untuk Pembelajaran Matematika Bagi Siswa SMA. Jurnal Inovasi Teknologi Pendidikan, 2(1), 49-63.

Fahmi, S., \& Marsigit. (2014). Pengembangan Multimedia Macromedia Flash dengan Pendekatan Kontekstual dan Keefektifannya terhadap Sikap Siswa pada Matematika. PYTHAGORAS: Jurnal Pendidikan Matematika, 9(1), 90-98.

Istiqlal, M., \& Wutsqa, D.U. (2013). Pengembangan Multimedia Pembelajaran Matematika SMA untuk Meningkatkan Motivasi dan Prestasi Belajar Matematika Materi Logika Matematika. PYTHAGORAS: Jurnal Pendidikan Matematika, 8(1), 44-54.

Khuzaini, N., \& Santosa, R.H. (2016). Pengembangan Multimedia Pembelajaran Trigonometri Menggunakan Adobe Flash CS3 Untuk Siswa SMA. Jurnal Riset Pendidikan Matematika, 3(1), 88-99.

doi:http://dx.doi.org/10.21831/jr pm.v3i1.9681

Mardiana, S. \& Qohar, A. (2017). Pengembangan Media Interaktif Berbasis Penemuan Terbimbing 'Transgeo' Pada Materi Translasi Untuk Siswa Kelas XI. AKSIOMA Jurnal Pendidikan Matematika FKIP Universitas
Muhammadiyah Metro, 6(1), 2027.

Novaliendry, D. (2013). Aplikasi Game Geografi Berbasis Multimedia Interaktif (Studi Kasus Siswa Kelas IX SMPN 1 RAO). Jurnal Teknologi Informasi \& Pendidikan, 6(2), 106-118

Nugraha, A.N.C., \& Muhtadi, A. (2015). Pengembangan Multimedia Pembelajaran Matematika Pada Materi Bangun Ruang Sisi Datar Untuk Siswa SMP Kelas VIII. Jurnal Inovasi Teknologi Pendidikan, 2(1), 16-31.

Rahmawati, A. \& Rizki, S. (2017). Pengembangan Bahan Ajar Matematika Berbasis Nilai-Nilai Islam Pada Materi Aritmatika Sosial. Jurnal Aksioma Pendidikan Matematika FKIP Univ. Muhammadiyah Metro. 6(1), 81-88.

Riyadi, S. \& Pardjono. (2014). Pengembangan Multimedia Pembelajaran Matematika Berbasis Komputer Untuk Kelas VIII SMP. Jurnal Inovasi Teknologi Pendidikan 1(2), 165 177

Yusri, R. \& Husaini, A. (2017). Pengembangan Multimedia Interaktif Menggunakan Microsoft Power Point Dalam Pembelajaran Matematika Kelas $X$ MA KM Muhammadiyah Padang Panjang. Jurnal IPTEK Terapan. 11(1), 1-8 